\title{
1. The roots of a relationship: religion, the state and its power
}

\subsection{AN HISTORIC TIE}

The interaction between the state and religious institutions goes back to the emergence of the state as a distinct legal or constitutional construct. The historical roots of statehood reach down at least to the classical Greek and Roman eras, but statehood as such has been coming to fruition only over the past few centuries. The European history of church and state is where the foundations of the current global discourse on the theme were laid. That is also where our current conceptions of statehood originate. ${ }^{1}$ From the outset European Christianity inspired a distinction between governmental and religious authority, inevitably leading to competition for supremacy. Law is not barren of normative aspirations such as justice and ethics, much of which are or were originally motivated by religious convictions. The knot tying law to religion cannot be untied. But before we can consider the nature of this knot we need to clarify some terminology.

\subsection{RELIGION: THE TERM}

A set of terms relating to religious matters is often used in conjunction, not always without confusion. These include 'religion', 'belief', 'faith', 'cult' and 'worship', words that are essential for a discussion of this nature.

In all manifestations of human society, faith, religion and religious practices are ubiquitous. These are profoundly human characteristics and activities, distinguishing, according to the major religions, man from beast. The complexity of the human condition and of society, however,

\footnotetext{
1 For example, Tierney (1996) 29-57. Tierney also describes the development of the foundations of (the only partially successful) religious tolerance among different Christian denominations and the emergence of scepticism, which opened the way for secularism as it is understood today.
} 
renders it possible to conceive of a variable continuum containing elements such as someone's world view, views, opinions, beliefs, convictions, faith, religion, loyalty, ethics, morals, culture, modality of worship and philosophy. Where and according to which criteria each of these elements might be placed on the range is open to debate, especially for the purposes of attempting to determine how a particular individual will react when confronted with the need to take a position on a religious issue.

The complexity of the human makeup makes a conclusive stance on these matters based on pure reason impossible. The individual's point of departure in such matters, as determined by personal temperament and related factors, will decide the response. And yet the state is required to deal with these characteristics and activities of individuals and societies in a consistent manner through the employment of the instruments of the law.

A vocabulary exists for dealing with these matters, but the language is not always employed with precision, often causing notions such as belief, faith, religion and so on to be used interchangeably. Due to the limitations of language as a medium of communication, the achievement of precision regarding words potentially bearing emotive and subjective meaning is not achievable. One can hardly be dogmatic about terminological choices in this context but, for a consideration of the interaction between religion and constitutionalism, at least some internal consistency is desirable.

This point is made exhaustively by Tiedemann, for instance in the first chapter of his book on religious freedom. ${ }^{2}$ Tiedemann points out that Cicero introduced the Latin word religio to indicate the precisely defined ritual practices followed in the worship of the Roman gods. Later Christian writers such as Lactantius and Augustine shifted the meaning of the word away from ritual action towards binding (religare) belief; in other words, the complete Christian belief system and the associated practices. In the course of the 'age of enlightenment', during the emergence of rationalism in the $17^{\text {th }}$ and $18^{\text {th }}$ Centuries, the notion of religion became detached from specific religious systems and rites to become a collective term indicating the whole variety of religious beliefs as a cultural phenomenon. The linguistic difficulties of giving meaning to imprecise words leads Tiedemann to distinguish between porous conversational notions on the one hand and terminology as a means of conferring precise scientific meaning on the other. He emphasizes the

2 Tiedemann (2012) 1-13. 
need to award meaning to a term in such a manner that it does not deviate too far from the colloquial meaning, but far enough to serve a clear purpose. Since the phrase 'freedom of religion' is a legal term employed for the purposes of regulation and adjudication, it requires a precise meaning. Tiedemann sees two possible reasons for the protection of the freedom of religion: either for the purposes of tolerance or in acknowledgement of human dignity.

John Witte, a seasoned contributor to the field, offers two approaches to the definition of religion. ${ }^{3}$ According to him, broadly speaking, religion 'embraces all beliefs and actions that concern the ultimate origin, meaning, and purpose of life, of existence. It involves the responses of the human heart, soul, mind, conscience, intuition, and reason to revelation, to transcendent values, to fundamental questions.' Witte's narrower description is that religion embraces 'a creed, a cult, a code of conduct, and a confessional community', on each element of which description he elaborates as follows:

A creed defines the accepted cadre of beliefs and values concerning the ultimate origin, meaning, and purpose of life. A cult defines the appropriate rituals, liturgies, and patterns of worship and devotion that give expression to those beliefs. A code of conduct defines the appropriate individual and social habits of those who profess the creed and practice the cult. A confessional community defines the group of individuals who embrace and live out this creed, cult, and code of conduct, both on their own and with fellow believers.

Witte's useful approach will be used as a guideline in what follows. We will use 'religion' in Witte's narrower sense, thus indicating a belief or convictions held by more than one person. 'Religion' therefore indicates not only the beliefs of a community or group of people sharing a personal view, but also the communal expression of their convictions in observable, external forms, often also including structures and teachings. ${ }^{4}$

Some additional elaboration on the terms 'faith' and 'belief' is called for. What a religious person believes can be described as that person's subjective faith. Unfortunately the conventions of everyday language are imprecise, since it happens not seldom that one hears or reads about 'a faith' when the intention is to refer to a religious system or structure. Used thus, 'a religion' and 'a faith' amount to the same idea. This usage will be avoided here in order to limit the meaning of 'faith' to personal

3 Witte (2006) 100-101.

4 Another way of describing various 'facets of religion' is presented by Gunn (2003), who, at 200-205, describes religion as belief, identity and a way of life. 
belief, that is, the individual's personal convictions regarding not only his or her own place in life, but also regarding the origins, progress and future of everything within one's knowledge, experience, expectation and speculation. Despite the best efforts of those who have sought answers to these matters by the exclusive employment of human reason, ${ }^{5}$ it stands to reason (wordplay intended) that profound personal convictions are powerfully and unintentionally influenced by one's foundational life experiences, domestic environment, parental and social teaching, and social interaction.

Seen thus, faith is built upon belief. Belief, however, does not relate only to religion. Believing something essentially means holding something to be true, such as that daylight is the factual result of the shining of the sun. Why there is a star that we call the sun and how it came into being is for most people a matter of religious belief. Put differently, those who accept creation as the unprovable origin of existence believe divine creation to be an existential truth. Although belief is therefore not reserved for religious faith, faith does depend on belief. ${ }^{6}$

Pamela Slotte opens her illuminating article on the interrelationship between the concepts 'religious' and 'secular' in European human rights law, in which she also attends closely to the difficulty of defining religion, as follows: ${ }^{7}$

The right to freedom of religion or belief involves the protection of something that tests the limits of the scientifically 'verifiable', but nonetheless is considered imperative to human rights law because of the presumed importance to human life. It is commonly assumed that we are dealing with assertions that come across as bearers of truth, yet are not provable in the sense that they cannot be verified or falsified by reference to a supposed objective reality. In this respect, the phenomenon of religion cannot be approached from a scientific standpoint. Yet, while 'informative' value cannot be determined, the meaningfulness of faith to human beings is not considered bound up with this fact.

5 One prominent modern example is that of John Rawls, who argues (inter alia in Rawls (1997) 799-800) that it should be possible to employ everyone's capacity for the conceptions of justice and the good to resolve political controversies rationally as citizens, regardless of people's adherence to opposing religions or 'comprehensive doctrines'.

6 Van der Vyver (2005) 503-506 points out that many jurisdictions avoid scrutinizing the exact meaning of 'religion' due to 'the conceptual difficulties', and that in international law freedom of religion and freedom of belief are linked, but that 'not every belief ... is included in the protection afforded to religion and belief'.

7 Slotte (2010) 231-232. 
Slotte demonstrates how, in the jurisprudence of the European Court of Human Rights, the meaning of 'religion' is determined by an understanding of the 'secular'.

The tension between religion and secularism lies at the heart of the difficulties that contemporary states are experiencing when required to deal with religious pluralism. Thus for example, with reference to German constitutional law, Kathrin Groh emphasizes the need, when defining religion for legal purposes, to find a balance between the subjectively held beliefs of individuals and religious communities on the one hand and the objective responsibility of the sovereign state to serve social well-being on the other. The legal definition is concerned with convictions concerning transcendental factors beyond a person's control that steer his or her existence. According to Groh attempts to broaden the definition for legal purposes beyond the minimum requirement of transcendency by adding enquiries into the content of the belief, will clash with the human dignity content of religious freedom itself, and also with the obligations of the state to maintain neutrality in matters of religion. ${ }^{8}$

As will emerge in our further discussion, the notions of secularism and neutrality loom large in matters concerning constitutionalism and religion.

\subsection{LAW AND RELIGION}

The human condition, especially in its social context, if it is to be peaceful, is known to all to require regulation. The obvious reason for this is that social order does not come about without rules. The most visible forms in which social regulation is cast are the law and religion. Appropriate legal regulation serves, inter alia, the interests of a fair and just society. Religious regulation is directed, inter alia, at denominational structures and their functioning. Law is intended to establish order for and among citizens within the state; on the other hand religious structures

8 Groh (2009) 84-87. For an exposition of the matter of the legal definition of religion in English law, see the 2013 judgment in $R$ (on application of Hodkin) $v$ Registrar General of Births, Deaths and Marriages para. 34 et seq. In para. 34 Lord Toulson remarked: 'There has never been a universal legal definition of religion in English law, and experience across the common law world over many years has shown the pitfalls of attempting to attach a narrowly circumscribed meaning to the word. There are several reasons for this - the different contexts in which the issue may arise, the variety of world religions, developments of new religions and religious practices, and developments in the common understanding of the concept of religion due to cultural changes in society'. 
and rituals serve the purpose of guiding the faithful when giving expression to their creed.

In the early development of societies, history teaches us that governmental, legal and religious leadership often overlapped, most famously in ancient Egypt, the Inca civilization, the Roman, Japanese and Chinese Empires, and in many African kingdoms. As societies develop an increased complexity of social relationships, state and religious leadership usually separate. Citizens living in developed and diversified societies, however, do not lose their need to understand and explain the world, life and human destiny - a need usually catered for by religion.

The nature and scope of law and of religion as such are matters calling for deeper consideration but, both being regulative and simultaneously applicable, it is inevitable that there will be interfaces between them, some harmonious and others conflictual. The South African Constitutional Court described this situation as follows: ${ }^{9}$

[R]eligious and secular activities are, for purposes of balancing, frequently as difficult to disentangle from a conceptual point of view as they are to separate in day to day practice. While certain aspects may clearly be said to belong to the citizen's Caesar and others to the believer's God, there is a vast area of overlap and interpenetration between the two. It is in this area that balancing becomes doubly difficult, first because of the problems of weighing considerations of faith against those of reason, and secondly because of the problems of separating out what aspects of an activity are religious and protected by the Bill of Rights and what are secular and open to regulation in the ordinary way.

The value of this dictum lies in the description of the interface between law and religion, but it also illustrates the predilection of the judge concerned (often shared by proponents of agnosticism and atheism) to relegate religion to the status of irrationality, as though there is little or no reason in faith. This is an obvious oversimplification. Undoubtedly believers of whichever conviction (including atheists and agnostics ${ }^{10}$ ) do

9 Christian Education South Africa v Minister of Education 2000 para. [34] per Sachs J.

10 Insofar as substantiation of the inclusion of non-denominational convictions in the broad category of religion might be called for, consider the wording of Article 2 of Protocol No. 1 to the European Convention on Human Rights, which reads as follows:

No person shall be denied the right to education. In the exercise of any functions which it assumes in relation to education and to teaching, the State shall respect the right of parents to ensure such education and teaching in conformity with their own religious and philosophical convictions. 
find the basis of their faith in an acceptance of that which cannot be proven. The route to that basis, however, always winds through reasoning, rationalization and accepted facts, be they assumed, historical or contemporary. This does not constitute a real distinction between law and religion: although legal argument is normally characterized by systematic reasoning, the foundations of legal reasoning are to be found in the acceptance of doctrinal presuppositions such as justice, fairness, dignity, equality, and so on. Subscribing to legal doctrine is therefore very similar to, and in some respects closely linked to, unprovable religious belief.

Both law and religion are dogmatic. 'Dogma' can be defined as 'a belief held unquestioningly and with undefended certainty'. ${ }^{11}$ Both theology and law as scholarly disciplines address dogma. The present project does not allow for an elaborate navigation through the rough seas of epistemology. It will have to be sufficient here, for the purposes of challenging the idea that religion is all belief and law is all reason, to briefly consider the nature of legal dogmatics. The valuable contribution of Aulis Aarnio ${ }^{12}$ can guide us here.

Aarnio is concerned with the legitimation of 'legal science', which is not understood to be part of the social sciences and is easily taken to be merely ideographic (dealing only with specific sets of fact) and not nomothetic (formulating general norms). He overcomes the linguistic difficulty that English is inclined to reserve the word 'science' for the physical and natural sciences by allocating the meaning of Rechtswissenschaft and science du droit to 'legal dogmatics'. ${ }^{13} \mathrm{He}$ then proceeds ${ }^{14}$ to

In Campbell and Cosans $v$ the United Kingdom (1982) the European Court of Human Rights para. 36 in effect dealt with a 'philosophical conviction' about corporal punishment of school children on the same level as a religious conviction. See also Eweida and Others $v$ the United Kingdom (EuCtHR) (2013) para. 79:

The Court recalls that, as enshrined in Article 9, freedom of thought, conscience and religion is one of the foundations of a 'democratic society' within the meaning of the Convention. In its religious dimension it is one of the most vital elements that go to make up the identity of believers and their conception of life, but it is also a precious asset for atheists, agnostics, sceptics and the unconcerned. The pluralism indissociable from a democratic society, which has been dearly won over the centuries, depends on it.

11 For example, Blackburn (2005) 104.

12 Aarnio (1997).

13 Aarnio (1997) 1-2. Robert Alexy, cited by for example, Andreas Voßkuhle (2012) 111 summarizes his conception of legal dogmatics as a class of rules (Sätzen) that relate to the posited norms and jurisprudence, but are not identical 
trace the history of the tension between natural law (originating in the theology and metaphysics of, for example, Aquinas and Suarez) and positivism and the line of rationalism running through both (e.g. Grotius and Wolff) and confronts the eventual and still perpetuating dilemma of the relationship between justness and legal certainty (predictability): 'If we consider reasonableness the only criterion of legal thinking, the difference between law and morals disappears altogether. Dispensing justice becomes dispensing justice in individual cases. Then the other essential element of law, predictability, disappears'. ${ }^{15}$

Justification is for Aarnio an essential element of dispensing justice, and 'a legal interpretation that is justified in a comprehensive and integrated way is in accordance with both law and justice'. ${ }^{16}$ Legal dogmatics has the functions of interpreting (in other words, clarifying the content of) and systematizing (in other words, further analysing by abstractly theorizing) the law. ${ }^{17}$ It is clear: only the most rigid rationalist can accept the notion that law is the product only of reasonable and rational thought, separated and distinct from considerations of morality, values founded upon belief (whether religious or ontological) and dogmatic conceptions constructed on foundational theory.

Law and religion thus share some features. Both have moral connotations, although with distinguishable implications - the one primarily temporal, the other primarily transcendental. Both are expressed in the form of norms that require obedience and are typified by procedural practices. In law, obedience is enforced by the state, whereas religious obedience is primarily a matter of individual conscience, although religious institutions also defend their integrity by enforcing conformity with prescribed norms and procedures on pain of exclusion or censure some extremely strictly and comprehensively, and others less so.

Most religious belief systems promote positive and peace-promoting attitudes such as tolerance and love, but they also distinguish sharply between believers and non-believers (in the belief system concerned). Where adherents of different religious groupings have to share space, resources and social institutions, they tend to become exclusive and

to them, relate to one another, are discussed and set out by a professional and have normative content.

14 Aarnio (1997) 7-17 - his first chapter under the title 'Reason and Authority'.

15 Aarnio (1997) 14.

16 Aarnio (1997) 16.

17 Aarnio (1997) 75, 285. 
competitive. Human history is strewn with examples not only of religious competition but also of religious intolerance, often resulting in bloody conflict. $^{18}$

In circumstances of religious tension occurring within a single legal jurisdiction, the conflict becomes a legal problem: how legally to regulate religious discord in a manner which will maintain and promote tolerance and social peace without discriminating against any of the religious groupings and without stepping outside the ambit of the law is a particularly intractable problem, since those who are entrusted with the responsibility of regulating and adjudicating are human and therefore exposed to their own religious (or profound ontological) convictions.

To contribute substantively to existing accounts of the nature of both law and religion is not the present intention. What is required here is no more than pointing out some major distinctions between them relevant to the purpose of this book. Having made mention of the dogmatic nature of the law as a scientific undertaking, it is necessary to anticipate and remove possible confusion regarding this discussion. We need not here be concerned with the distinction between the two scholarly disciplines of law and theology, since we do not need to transcend the boundaries of law, which is the present field of investigation, and venture into the domain of theology. Mention of dogma is relevant, however, because the dogmatic nature of neither law nor religion is limited to legal scholarship and theology. Theological dogma obviously varies according to the religion upon which it is constructed - Roman Catholic dogma for example differs fundamentally from any of the dogmas included in Hinduism. It is important to note a parallel truth regarding legal dogmatics: different perspectives on law produce divergent dogmatic approaches. For instance, understanding law to be essentially a collection of binding injunctions resulting from sovereign prescription leads to dogmatic stances different from understanding law to be the product of principled formulation in accordance with foundational values. Considering law to be the preserve of reason in contrast to faith as the source of religion is a stance in legal dogmatics. This last mentioned dogmatic stance incidentally also supports the view that the state is secular in the sense of being isolated from religion. These are matters that will require further attention as we proceed.

Essential differences between the phenomena 'law' and 'religion' can, for our present purposes, be highlighted sufficiently by means of mentioning some of their distinguishing salient characteristics.

18 See for example, Christenson (2013). 
Religion belongs in human existence, both profoundly personal and public. Personal religious belief underpins communal practices. Those sharing the same religious convictions usually develop rituals, liturgies, dogmas, cults and in many cases structures or spaces as sites for communal devotion. Sincere adherence to a religion is unfailingly preceded by personal conviction. Education, social environment, culture and example certainly are compelling factors in the process of personal acceptance of a religion, but ultimately authentic religious belief depends fully on internal, unforced conviction. ${ }^{19}$ Loss of faith essentially leads to the termination of membership of the religious community concerned, exclusion from the real or perceived privileges and benefits of such membership, and in some cases to social marginalization and ostracism. ${ }^{20}$

Law, on the other hand, is primarily a normative construct. It is necessarily public: the proverbial Robinson Crusoe no doubt had personal religious convictions but no need for law until Friday arrived on the scene. Law does not require personal or public subjection or belief in its content but demands obedience, not as an optional choice, but as an enforceable result. Being subject to the law does not require education or acculturation but mere presence under the jurisdiction concerned. The

19 No doubt every religious community or movement has its share of insincere and half-doubting fellow travellers but no religion can retain the integrity of its following by the prohibition of apostasy: forcing an individual to believe or to disbelieve anything is not possible.

20 This description of religion may challenge the position taken here that agnosticism and atheism are essentially religious stances, because structures and rituals do not normally characterize the proponents of agnosticism or atheism. Put differently, opposition to structured and organized religion does not constitute $a$ religion but it is 'religious', as in being based upon a profound belief. A profound religious conviction does not need to be organized or institutionalized. A useful test for the religious nature of agnosticism and atheism is their rejection of (other) religious beliefs as untrue, accepting only their own perception of the truth, albeit 'anti-religious'. Consider for example the arguments presented by Webber (2009) 43:

The fact that the freedom [of religion] finds its origin in religion does not mean that it is trapped within a particular conception of religious orthodoxy or even - this is the important point - that its moral justification is limited to self-consciously religious beliefs. ... [T] he very idea of religious freedom presupposes a willingness to recognise commitments that operate in a comparable way whether or not they conform to a preconceived idea of religion. ... After all, for the religious zealots of the Reformation era, the other's faith was not religion; it was the most profound and dangerous error.

In the current context 'non-religious' beliefs also distinguish themselves from the law in that they are human activities as opposed to normative constructs. 
transgression of legal rules, when enforced, has clear consequences, generally detrimental to the transgressor, enforced by the compelling authority of the state. Nevertheless, law is not disconnected from foundational human stances: its fairness is measured in terms of conceptions of justice and its effectiveness in the absence of specific enforcement is dependent upon the acceptance of its legitimacy by the society in which it applies.

Law and religion thus occupy different areas of personal and social existence. Religion involves individual and communal activity, whereas law as a social system or structure constitutes a passive normative framework. $^{21}$ The difficulty on which we are focused here lies in the inescapable need for the law to regulate matters concerning religious activity in a manner that is fair to all under the equally unavoidable circumstance that the foundational suppositions upon which legal norms are created cannot be ignored as though they do not exist.

Mark Witten, writing in the Canadian context, compactly summarizes the typical secular response to the difficulties occurring at the interface between constitutionalism and religion: ${ }^{22}$

Canadian constitutional law is not neutral, but is rather a political culture that is partisan to its own informing values. As Professor Benjamin Berger contends, Canadian constitutional law shares the political culture of liberalism, an ideology that birthed the modern democratic state and its institutions. Berger argues that law inevitably casts religion in a manner that comports with its own cultural assumptions: religion as an individual experience, religion as a private matter, and religion as an expression of autonomy. Thus, for religion to be understood, recognized, and accommodated at law, it may be forced to resonate with the judiciary's preferred construction of religion. In addition, it also follows that law's comprehension and treatment of religion is deeply influenced by liberalism's epistemological assumptions, which are the assumptions of rationalism. Rationalism presumes a way of knowing that elevates reason and considers the criterion for truth to be exclusively intellectual and deductive, as opposed to sensory, mystical, or experiential. Moreover, because the rationalist philosophy of the Enlightenment developed in reaction to religious power, its assumptions hold unique implications for law's treatment of religion.

21 Law is naturally 'practised' by professional lawyers and actively created and amended by legislators, administered by bureaucrats and governments, but it is not after its manifestation dependent for its existence, as is the case with religion, on being practised.

22 Witten (2012) 92-93. 


\subsection{CHURCH AND STATE}

The state is the primary domain of the law, and 'the church' that of religion in its public manifestation. The word 'church', usually associated with Christianity, does not have an inclusive meaning that covers the spectrum of religions, but is nevertheless used by many to indicate the tension between law and religion in the phrase 'church and state'.23

The controversial Roman emperor Constantine 'the Great', founder of Constantinople, proclaimed the Edict of Milan in 313, thereby ending the Roman prosecution of Christianity and laying a foundation for religious tolerance, although such tolerance had a chequered career in the subsequent centuries. Constantine's embrace of Christianity also initiated an era of significant overlapping in Europe of the interests and powers of church and state. ${ }^{24}$

The issue of the division of authority between church and state was accentuated in the $5^{\text {th }}$ Century when Aurelius Augustinus taught about two cities, one the city of God for the pious and the other the city of sinful man, the two cities uncomfortably coexisting until the end of time. ${ }^{25}$ In 494 Pope Boniface laid down the notion of two powers, the one sacred (that of the Pope) and the other royal (that of the Emperor). ${ }^{26}$ In the $11^{\text {th }}$ to the $13^{\text {th }}$ Centuries, during the Papal Revolution, this was developed into the two swords doctrine, separating the temporal (the state) from the spiritual (the Roman Church). ${ }^{27}$ At the hands of Luther ${ }^{28}$ and Calvin ${ }^{29}$ in the $15^{\text {th }}$ Century the Reformation introduced a doctrine of two kingdoms as a variation, but also a continuation of the essential idea

23 The publishers of the Journal of Church and State (Oxford University Press) for example, describe its purpose as follows: 'The Journal of Church and State seeks to stimulate interest, dialogue, research, and publication in the broad area of religion and the state. JCS publishes constitutional, historical, philosophical, theological, and sociological studies on religion and the body politic in various countries and cultures of the world, including the United States.'

24 See for example, Temperman (2010a) 13-17.

25 Cf. for example, Duijnstee (1930) with a useful overview at 290-295.

26 Cf. for example, Rommen (1935) 258-260.

27 See for example, Rommen (1935) 255-258, 260-266.

28 See for example, Pierard (1986), especially 193-195 and Heckel (2013) $38-42$.

29 Calvin explicitly rejects the papal claim to 'the right of both swords' in The Institutes of the Christian Religion Chapter 11 sections 9-16. 
that people are simultaneously bound to submit to both the religious and secular authorities, each within its domain. ${ }^{30}$

Ending the Thirty Years War that raged devastatingly across Western Europe to a large degree between Catholics and Protestants, the Peace of Westphalia of 1648 confirmed the notions of the ius emigrandi (subjects of a ruler who did not share his religion had the right to emigrate peacefully), and of cuius regio, eius religio (first expressed in the Peace of Augsburg declared in 1555 between Catholics and Protestants in the 'Holy Roman Empire of the German Nation'), thus also serving as an historical high-water mark for the Protestant Reformation ${ }^{31}$ and the geographical division of Europe between Roman Catholicism and Reformational Protestantism. An effect of Westphalia was also the emergence of religious freedom as the first constitutionally protected fundamental right, in that the parties agreed that citizens whose religion differed from that of their rulers should not be persecuted by the rulers. ${ }^{32}$

The European $17^{\text {th }}$ and $18^{\text {th }}$ Centuries were also the dawning era of scholarly genius, social and philosophical exploration, religious turmoil, the opening up of what the Europeans considered to be the 'new world', and the gaining of access to and domination of the riches of the regions of the globe inhabited by 'uncivilized' people. In this intellectually and politically turbulent golden age it was also not strange if lawyers like Descartes and Leibnitz blossomed into mathematicians, or for natural philosophers like Newton to spend as much - if not more - time on fervently studying the Bible as on contemplating mathematics and

30 The Synod of Bern of 1532 for example, took the following position (cited and translated by Bruening (2005) 66):

The greater and more sublime is the spiritual and heavenly government ... The lesser, which belongs to the Bernese magistrates, is the earthly government. The Christian falls under the jurisdiction of both. In his conscience, which God alone judges, he belongs to the spiritual government without the intervention of any creature. But with regard to his body and temporal goods, the Christian is subject to the external sword and human administration.

31 See for example, Christenson (2013) 740.

32 Croxton and Tischer (2002), under the entry 'CUIUS REGIO; EIUS RELIGIO':

The Peace of Westphalia sharply limited the doctrine by setting 1624 as the 'normal year' for religious affairs: whatever religion was practiced at that time was allowed to continue, and although the ruler could change the state church, he could not interfere with the public worship of his other subjects. The Peace of Westphalia also diverged from the cuius regio principle because it guaranteed freedom of worship in private homes and the right of religious dissidents to emigrate. 
physics as an endeavour to unravel the assumed divine code of creation. ${ }^{33}$ It was the era of Rousseau, Hobbes, Montesquieu, de Vattel and John Locke, who urged the drawing of clear lines between 'the business of civil government from that of religion'. ${ }^{34}$

Natural law as the product of the assumed rational human mind became a powerful influence on the emergence of constitutionalism at this time. Thomas Hobbes more or less sealed the distinction between the spiritual and temporal, church and state, in his Leviathan of 1651, where he wrote: 35

How then can we be obliged to obey any minister of Christ, if he should command us to do anything contrary to the command of the king, or other sovereign representant of the commonwealth whereof we are members, and by whom we look to be protected? It is therefore manifest, that Christ hath not left to his ministers in this world, unless they be also endued with civil authority, any authority to command other men.

The Enlightenment of the $17^{\text {th }}$ and $18^{\text {th }}$ Centuries can be understood to have been the era during which the individual gained particular prominence in law, society and philosophy. Zafirovski, for example, rightly points out that what are generally assumed to be the foundational values of $21^{\text {st }}$ Century constitutionalism - such as liberty, equality, justice, democracy, inclusion, human rights, dignity, well-being and happiness, humane life, civil liberties, scientific rationalism, technological and social progress and optimism, economic prosperity, free markets, secularism,

33 For example, Dolnick (2011) 211.

34 For a clear précis of this history and thinking, see Witte (2006) 212-222 and also Witte (1996) Chapter 4. Loth (2007) 1737 neatly draws the picture of the rise of modernism after the Peace of Westphalia as follows:

scientists like Newton changed the picture of the universe beyond recognition, describing it as a clock in which every event was connected through lawlike causal generalizations. Starting with Descartes, philosophy came into the grip of three dreams: the dream of a unified science (Newton), a unified method (Descartes), and a unified language (Leibniz). This 'quest for certainty' also had its impact on social thinking. Political philosophy changed from the art of politics from Machiavelli to the picture of society as a construction sketched by the social contract philosophers (Hobbes, Rousseau, Locke).

35 In Chapter 42 of Leviathan in the paragraph marked in the margin 'From the authority Christ hath left to civil princes'. 
pluralism and diversity, individualism, universalism and humanism - all originated in the Enlightenment. ${ }^{36}$

This was the atmosphere under which the iconic Constitution of the United States was conceived, as the American Founding Fathers were putting the ideas of the Enlightenment geniuses of political philosophy into practice. The subsequent influence of the US Constitution around the globe, its interpretation and application as an exemplar of progressivism, political maturity and balanced advancement can hardly be measured in absolute terms, but it was immense up to at least the end of the $20^{\text {th }}$ Century. ${ }^{37}$ The American influence was not the only factor that steered approaches elsewhere in the world, but the manner in which American law deals with religion in the constitutional context has had a discernable worldwide echo. This is not to say that there is anything approaching consensus among Americans on this issue, but clear trend lines can be drawn, especially regarding the jurisprudence of the Supreme Court in Washington.

The constitutional pivot around which the developments in this context turn is the first phrase of the First Amendment of 1791, which states: Congress shall make no law respecting an establishment of religion, or prohibiting the free exercise thereof. The manner in which this 'nonestablishment' and 'free exercise' clause has been interpreted over the past two centuries has varied. Since 1947, coinciding with the current era of the blooming of constitution-writing around the world, the emphasis in American law has been on strict separationism, that is, the supposed isolation of state action from religious influence.

Some Americans consider the Constitution to stand as a substitute for religion in the public domain. ${ }^{38}$ The idea that the Constitution is the foundation of a 'civil religion' is not a recent development, however. As

36 Zafirovski (2011) Chapter 1 under the heading 'Liberty, Life, and Happiness for All: The Ideals and Legacies of the Enlightenment in Modern Societies Revisited'.

37 Temperman (2010a) 118-119 lists some 28 Constitutions adopted between 1900 and 2006 containing 'non-establishment' clauses.

38 Davis (2011) 97 describes the American civil religion as follows:

The Pledge of Allegiance is our creed, the Constitution is our scripture, and our founding fathers are our patriarchs. We are devoted to democracy, we pray for our progress, and we are committed capitalists. Our prisons are our civil religion's purgatory, where we hope the criminal perpetrators prove penitent. We celebrate our saintly soldiers on Memorial Day, and we praise our political prophets such as Martin Luther King, Jr. 
far back as 1839 John Quincy Adams dramatically stated: 'Fellowcitizens, the ark of your covenant is the Declaration of Independence. Your Mount Ebal, is the confederacy of separate state sovereignties, and your Mount Gerizim is the Constitution of the United States. ${ }^{39}$

In 1990 Stephen Griffen wrote: 40

Claims that the US Constitution is a magnificent document which "embodies the American spirit, the American Dream', are not really open to rational debate. They are expressions of quasi-religious faith and patriotic sentiment and are not advanced on the basis of argument. It is questionable whether such assertions even have the Constitution as their subject - they seem to use the Constitution as a symbol for the nation as a whole.

In 1971 the Supreme Court handed down its judgment in Lemon $v$ Kurtzmann ${ }^{41}$ in which a test was devised for the conformity of laws with the non-establishment element of the First Amendment. This 'Lemon test' states as follows: 'First, the statute must have a secular legislative purpose; second, its principal or primary effect must be one that neither advances nor inhibits religion; finally, the statute must not foster an excessive government entanglement with religion.'

It is interesting to observe that the test is concerned with 'religion' as a phenomenon, and not 'a religion'. In effect, the Supreme Court therefore required schools that wished to receive government funding to denude their teaching completely of any religious connotations and to concentrate on 'secular' education. This result was endorsed by Justice O'Connor in 1984 when she refined the first element, 'a secular legislative purpose', with an 'endorsement test' in Lynch $v$ Donnelly. ${ }^{42}$ She proclaimed that ' $[t]$ he proper inquiry under the purpose prong of Lemon, ... is whether the government intends to convey a message of endorsement or disapproval of religion'.

In his review of recent Establishment Clause jurisprudence, Samuel J. Levine effectively demonstrates how erratic the judgments are, and points

\footnotetext{
39 Cited House (1999) 204.

40 Griffen (1990) 200.

41 Lemon v Kurtzman 403 U.S. 602 (1971). Cf. Laycock (2010) at 103-122 (containing an excerpt from Religion in American Law: An Encyclopedia).

42 Lynch v Donnelly, 465 U.S. 668, 691 (1984).
} 
out ${ }^{43}$ that 'the growing religious diversity in American society, accompanied by increasing numbers of self-identified secularists or nonbelievers, adds another level of complexity to an Establishment Clause analysis'.

The common meaning of 'secular' is 'wordly' or not-sacred. Thus the secularization of the state can superficially be understood to point to the process of the termination of the ecclesiastical domination of government. This would appear to be the root of the language of the US Supreme Court in its judgment in Lemon $v$ Kurtzman, where the word 'secular' is employed many times without an explanation of its meaning being offered. Thus the imperative of a 'secular legislative purpose' was not explained, other than through the distinguishing of 'the secular' from 'the religious'. Etymologically the distinction, considered by the Supreme Court to be trite, is most probably founded on the two cities, two swords, two kingdoms doctrines mentioned above.

The American example, having been greatly influential, is however by no means the only model that is followed by contemporary constitutional states and in international law. Constitutions in which the American non-establishment approach is not followed make interesting reading regarding the understanding of the 'separation of church and state'. The contemporary constitutional arrangements concerning religion in various representative countries will be considered in Chapter 4. The approach of the courts in some other systems will be discussed in Chapter 6. Further attention will be given to the meaning of secularism, inter alia, in Chapter 7.

At least four phases in the history of 'church and state' can therefore be identified:

- A pre-differentiation phase where law and religion, 'state and church', overlap.

- The emergence of the two cities, two kingdoms, two swords doctrines.

- The establishment of the notions of secular liberalism running concurrently with the emergence of the modern state.

\footnotetext{
43 Levine (2012) 778. See also McConnell (2009) 100:
}

For 16 words that remain completely unchanged from their adoption some 215 years ago, the Supreme Court's interpretation of the Religion Clauses of the First Amendment of the United States Constitution have shown remarkable malleability. Arguably, the court's interpretation of these Clauses has changed more often, and more dramatically, than of any other provision of the Constitution. 
- The current phase of the post-liberal, post-secular confrontation by the state of the realities of religious pluralism.

\subsection{POWER AND JUSTICE}

The obvious reason for the importance of the state for religion is that the state is endowed with compelling power, ${ }^{44}$ including over matters that affect the practice of religion. The manner in which this power (or authority, which is the more civilized expression) is exercised in a particular situation relates directly to the nature of the particular state and the moral considerations underlying the legal order within which the state and its structures have been conceived and are operating. To illustrate: if the authority of a state emanates exclusively from the ability of the government to impose its will on all under its jurisdiction under the threat of aggression, one has to do with a dictatorship or autocracy that is exercising its power in terms of a morality of violence; if, on the other hand, the authority of a government is motivated by an ability to persuade those under its jurisdiction to conform to its stated wishes, some form of open democracy is in place, operating on a morality of legitimacy.

No doubt a legitimate democracy is to be preferred, but even in such a case the state must have the means of enforcing its authority, if needs be, by the judicious employment of force. It is this indispensable element of compelling force that distinguishes the state from most other social institutions. The regulatory framework within which state authority is exercised is the law. Legal regulation distinguishes itself from most other forms of social regulation in that constantly behind it is the potential of enforcement by means of the application of the state's monopoly on the permitted application of its institutionalized superior might.

44 Max Weber famously defined the state as follows (Weber (2010) 8): 'Staat ist diejenige menschliche Gemeinschaft, welche innerhalb eines bestimmten Gebietes - dies: das “Gebiet", gehört zum Merkmal - das Monopol legitimer physicher Gewaltsamkeit für sich (mit Erfolg) beansprucht.' (Freely translated: The state is that human community that successfully claims for itself the monopoly of legitimate physical empowerment, typically within a specified territory.) Although Weber's definition of a state is sometimes contested, the element of coercive power can scarcely be excluded from its definition. See for example, Hoffman (1995) Chapter 3, where he defines a state as 'an institution which claims a monopoly of legitimate force for a given territory', whereas government 'pertains to the pursuit of order within a community'. 
The most profound question that needs to be answered in the process of one's grasp of the nature of the state and of the law as an abstract but real instrument in its hands by means of which its authority may be exercised legitimately concerns the source of the state's power. The answer to this question inescapably requires one to make a moral if not a religious choice. The instinctive response in established Western legal thinking to the question of where power originates is to proffer theories of liberal democracy as the foundation of the authority of the state.

Liberalism has had much to do with the development of the notion of constitutionalism (with which we deal in Chapter 3), and its current effect on jurisprudence and academic work continues to be powerful. This is demonstrated clearly by the currency of the names of liberal philosophers such as John Locke, Ronald Dworkin and John Rawls in the context of our current theme. But it has to be asked: is liberalism an sich a prerequisite for contemporary constitutionalism, democracy, human rights, and constitutional and international jurisprudence? For the liberal(ist) the answer will obviously be 'yes', but does that mean that liberalism must continue to dominate constitutional discourse and disqualify other approaches to constitutionalism? Is constitutionalism exclusively a liberal dogma? Is liberalism a shibboleth for those seeking admission to the global debate on constitutional balance and justice? In Chapter 7 below it is argued that this is not the case. The world of constitutionalism is labouring under the shortcomings of fictitious constitutional constructs and terminology produced over centuries by hugely influential liberal thinkers. Alternatives to these ubiquitous concepts are not readily available, but there is a global need to fill the vacuum that the shrinking credibility of classic liberal thinking is leaving behind.

Where should we then turn to find an answer to the essential question of the origins of state authority? If the answer is not to be sought in pragmatic formalism, ${ }^{45}$ the search calls forth considerations of religious belief (even if that belief is 'secular'). Involving belief in one's understanding of the source of state authority harbours the possibility of (re-)merging 'church' and state, but such a merger is not only impossible (except, theoretically, in the case of monist theocracies such as are in evidence in the Muslim world) without injustice to other religions, but is also not required. A religious explanation of state authority does, however, generate the problem of inconsistent and even irreconcilable understandings of the sources of the authority of the state, particularly in

45 Möllers (2007) seems to imply that pragmatic formalism reigns supreme in current general German constitutional thinking. 
a religiously plural society: different religions have different explanations for authority, a fact that goes some way towards explaining the refuge that many take behind secularism at the cost of their religious convictions. ${ }^{46}$

The logic behind state secularism is that if the state, the law and authority do not need to be justified in religious terms, the blandness of secularity offers an escape to assumed harmless neutrality. This is, however, by no means a satisfactory result, because it leaves the most profound human attribute, religious belief, unrequited. On the other hand, making choices explicitly based on religious considerations is guaranteed to offend those with dissimilar convictions. That is nevertheless exactly the result also of imposing the convictions of liberalism, secularism, agnosticism or atheism on the state and its organs. To this dilemma we will return in the final chapters of this book.

Measuring whether or not the state is performing its tasks and exercising its authority as it should involves invoking standards of justice. Being slightly less profound (though by no means removed from profundity) than a view on the sources of state authority, positions taken on the nature and requirements of justice are nevertheless also determined by moral points of departure. They are committed to predetermined values, inevitably based on religious belief. Unsurprisingly there are therefore various ways in which justice may be construed. ${ }^{47}$

Fortunately (rendering it unnecessary here to launch into a comprehensive deliberation on justice) we have the benefit of a universally instinctive human reaction to the question of fairness and justice. This reaction is often referred to as 'reciprocity', also called 'the golden rule', and has been professed with slight variations by a wide range of religions through the ages. Ulpianus, for instance, famously coined the rule suum cuique tribuere. ${ }^{48}$ An excellent treatise on this golden rule as a guide for ethical conduct was published in 1996 by Jeffrey Wattles. He expresses it in the following model with a major premise, a minor premise and a conclusion: ${ }^{49}$

46 A particularly revealing topical example of this is the tension in Turkey between secularity and Islam.

47 Literature through the ages dealing with the notion of justice abounds. For a compact overview see for example, Ritsert (2012) Chapter 1 and the sources cited there.

48 See for example, Ritsert (2012) 15, where he also points out how Kant developed it into the position that it is unjust to suppress the free will of a person, and thus infringe upon his or her dignity.

49 Wattles (1996) 165-166. 
1. Treat others as you want others to treat you.

2. You want others to treat you with appropriate sympathy, respect, and so on.

3. Therefore, treat others with appropriate sympathy, respect, and so on.

Flores describes reciprocity, which was originally attributed to K'ung-futzu (Confucius), as 'a principle firmly entrenched in the "Eastern" comprehension of the world that is also present in the "Western" one' and which is implicit in the notion of the rule of law, and even finds it expressed by exponents of liberalism such as Dworkin and Rawls. ${ }^{50}$

Citing Paul Ricoeur, Wattles describes ${ }^{51}$ justice as being 'characterized as a social institution, as involving communication, listening to arguments, and arriving at a decision backed up by force; justice also is an idea or ideal of equitable distribution'.

Dealing fairly with religious pluralism requires this kind of justice. The success that courts have achieved while dealing with religious matters in various systems will be considered in Chapter 6.

\subsection{A KNOT THAT CANNOT BE UNTIED}

History, philosophy, language and morality have all been engaged in the process of interweaving the very human institutions of law and religion, and they continue to do so. Simultaneously little doubt can remain that failure to distinguish appropriately the social and personal realms within which each exists and is practised creates grave difficulties, especially in the diversified societies of the $21^{\text {st }}$ Century. Where 'church and state' are not properly separated, where the state attempts to suppress religion, where religious institutions attempt to prescribe proper conduct to the

50 Flores (2013) Chapter 6 passim. At 77 he writes:

The principle 'reciprocity' attributed to Confucius is closely related not only to several of the principles integral in our conception of the 'rule of law', such as 'isonomy', 'generality', 'constancy', 'the harm principle' - as a justified limitation to liberty - and limits to 'majority rule', but also to the classic one contained in the Greek word isotimia and to the modern 'equal concern and respect' advocated among others by Dworkin and Amartya Sen, following John Rawls and his 'difference principle'.

51 Wattles (1996) 159. 
government, where the state promotes one religious entity to the detriment of others in a religiously plural population, trouble, tension, confrontation, competition and dissatisfaction flourish.

Taking flight behind inaction and disinterest regarding religious matters is also a sure recipe for putting strain on the relationship between citizens (in other words, individuals who are in their existential nature religious) and the state as the bearer of compelling legal authority.

We must therefore conclude that, while law and religion represent fully distinct sets of norms, there is a link between them that cannot be broken: it is a knot that cannot be untied without negative consequences and one which is ignored or pushed aside only at the cost of a loss of legitimacy and credibility. 